\title{
IMMUNOGENETIC ANALYSIS OF HYBRID POPULATIONS OF THE GREEN FROG COMPLEX PELOPHYLAX ESCULENTUS-RIDIBUNDUS OF THE FAUNA OF UKRAINE
}

\author{
(C) I. Kozynenko, E. Zhalai
}

For purposes of unravelling the development of the hybrid complex Pelophylax esculentus-ridibundus an immunogenetic method of skin transplantation was applied for assessing the variability of hybrids and parental species according to levels of expressed histocompatability. Animals from the different types of hybrid systems known in Ukraine were studied. For allodiploid hybrids dominance of genes of major histocompatibility complex of frog edible was established

Keywords: hybrid complex Pelophylax esculentus-ridibundus, immunogenetic studies, allo-, xenotransplantation

Для вирішення питань формування гібридного комплексу Pelophylax esculentus-ridibundus застосований імуногенетичний метод пересадки шкіри, який дозволяє визначати мінливість гібридів $і$ батьківських видів за антигенами гістосумісності. Досліджені тварини з різних типів гібридних систем відомих для України. Для алодиплоідних гібридів встановлено домінування генів головного комплексу гістосумісності ставкової жаби

Ключові слова: гібридний комплекс Pelophylax esculentus-ridibundus, імуногенетичні дослідження, ало-, ксенотрансплантація

\section{Introduction and review of the literature}

The Western Palearctic green frog Pelophylax esculentus-ridibundus complex for about 50 years has been a model for studying the structure of hybrid vertebrate groups and processes that accompany them. This continued interest is due to the hybridization of species of green frogs, which easily occurs in vivo. These species have a well defined morphological and genetic hiatus, whereas the hybrids are featured by an alloploid structure of the genome [1].

Numerous studies have shown that the stable allodiploid structure of the hybrids is maintained by the elimination of the genome of one of the parental species at the premeiotic stage. Subsequently the genome of the other parental species is inherited without recombination [2]. This particular type of reproduction has been has been named as "hemiclonal". Features of premeiotic elimina-tion and, consequently, the structure of hybrid popula-tions have a geographic mosaic. Accordingly, hybrids in different parts of the range may be diploid or triploid [3]; only females [4] or vice versa males [5, 6], and may have a similar to the parental species equal sex ratio [7]. Finally, hybrids can produce gametes of the same type, in which case they contain only one genome of the parental species [8] or two [9]. The elimination of genes can affect both the edible and marsh frog [5]. Features of the hybrids even within one area are largely determined by the structure of hybrid populations and the pattern of cross-breeding. Almost all such cases of diverse hybrid po-pulations have been recorded in Ukraine [10]. The reason for this heterogeneity is most likely the spatial genetic differentiation of the parental species, which in its scope can match a taxonomically significant level [11].

A promising study of this issue can be accomplished by using methods which can characterize variable portions of genome. This is because they provide a better insight into the differentiation of populations and species, as well as allow for distin-guishing between genetically close individuals. Rather than taking into account individual loci, we consider the research would be more appropriate by carrying out an immunogenetic analysis involving the major histocom-patibility complex, which is of polygenic nature (due to multiple non-allelic closely linked genes whose protein products are of similar structure and perform identical functions) and highly polymorphic because of the presence of many allelic forms of the same gene. Up to now this method has not lost its value in successfully determining the genetic identity of individuals.

Amphibians are proved to possess a major histocompatibility complex homologous to warm-bloo-ded animals, and, therefore, can display rejection reac-tions of the immediate type, allowing the study of population structures involving immunogenetic methods of tissue transplantation [12]. In green frogs the number of alleles of the major histocompatibility complex (MHC) is one of the largest among amphibians, so the method of transplantation in this case has a potential for a high resolution [13]. In addition, another important advantage of this method is the ability to not cause any damage to frog populations as far as the studies are conducted in vivo.

\section{Goal}

The goal was to identify the particular structure of hybrid populations and hybrids of the complex of green frogs Pelophylax esculentus-ridibundus in Ukraine, using immunogenetic methods of skin transplantation. The objectives of the study were to: find out for the allodiploid hybrids the parent species responsible for providing the dominant set of MHC genes, estimate the distance between the parental species and the hybrids, determine whether the genome elimination related to the hybrid is linked with the dominance of the major histocompatibility complex genes of the marsh or either the edible frog. 


\section{Materials and research methods}

\section{1. Materials}

Experiments were conducted on the European green frog hybrid complex Pelophylax esculentusridibundus: $P$. ridibundus - marsh (R), P. esculentus - edible (L), as well as hybrid allodiploid forms of $P$. esculentusridibundus (E) from various population systems. In particular: REL - marsh, edible and hybrids, RE - marsh and hybrids, LE - edible and hybrids, E - only hybrids.

Selection of the studied localities was concentrated on zones where hybridization of green frogs occurs.

Middle Dnipro Basin. Populations: REL (Novobilychy, vicinity of Kyiv); LE (Baryshivka, Kyivska Oblast, Nizhyn, Chernihivska Oblast) and L (edible frog) (Lisnyky, Kyivska Oblast). sa Oblast).

Lower Danube. RE population (Vylkove, Ode-

Transcarpathian Lowland. RE population (Tsehlivka, Zakarpatska Oblast); E population: Minay (Zakarpatska Oblast, vicinity of Uzhhorod).

Siverskiy Donets Basin. RE population (Haydary, Kharkivska Oblast).

A total of 603 mature individuals of the green frog complex Pelophylax esculentus-ridibundus were studied. This number included 168 marsh frogs, 160 edible frogs, 275 hybrids. After the experiments, the animals released to their natural habitat.

\section{2. Research methods.}

Morphological analysis: was applied for the preliminary identification of individuals belonging to a particular species or hybrid. We used features having the greatest diagnostic value [6].

The method of transplantation of skin graft. As a basis we chose the classic method of tissue transplantation, designed for tadpoles of $R$. catesbeiana and modified for frogs, which completed metamorphosis [14]. After sorting the frogs on grounds of the morphological analysis and a two-week adaptation period, allo- (the exchange of grafts between animals of one species) and xenotransplantation (the same between animals of different species) was carried out. Autografting served for control.

Xenotransplantation studies focused on the reaction of the parental species towards the hybrid and the hybrid towards the parental species (Fig. 1).

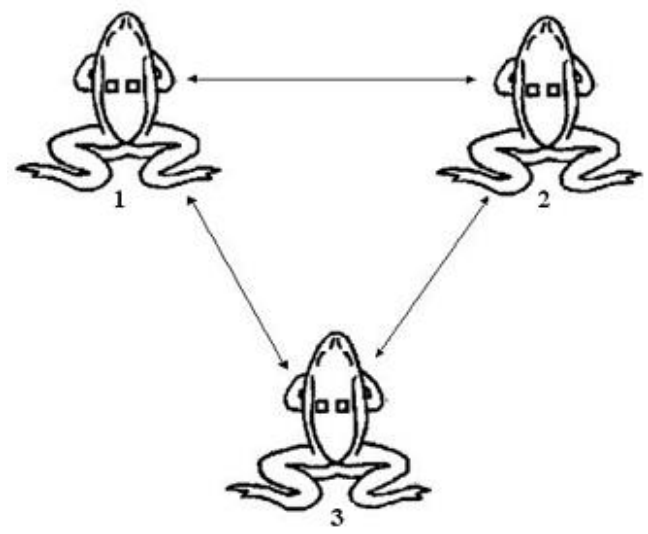

Fig. 1. Exchange of grafts between the frogs in the xenotransplantation experiments: 1 - marsh frog; 2 - edible frog; 3 - hybrid
A total of 1206 operations were accomplished. Of these 420 were allotransplantations, 758 - xenotransplantations, and 28 - autotransplantations.

Generally the transplant response is estimated at a qualitative level. The criteria are the beginning and end of destructive changes. We have introduced a quantitative assessment of the response in points [15]. The experimental results were evaluated according to the following parameters: length of the latent phase of graft survival time and the rate of rejection. The length of the latent phase is the time (in days) from the date of the surgery to the date of recording of the first manifestations of rejection. The time length of graft survival is the number of days from the day of the operation to the day of complete rejection. The rejection rate corresedibles to the regression coefficient describing temporal changes in the mean reaction strength (in points) for each particular experimental group.

Biochemical gene marking. After the immunogenetic studies there was a need to verify the composition of the experimental groups of green frogs. For this purpose genetic identification was conducted by using the method of electrophoresis in $7.5 \%$ polyacrylamide gel. The diagnostic for frogs locus lactate dehydrogenase (Ldh-B) was chosen for the analysis [16]. Samples were taken of the distal phalanx of a digit with a small piece of flipper one of the hind limbs.

Statistical analysis of the data. All received transplantation data were digitized, put into spreadsheets (Microsoft Excel v. 9.0.) and processed in Statistica for Windows v. 6.0.

\section{Results}

For all types of transplantations (except for autotransplantations in which grafts are fully accepted by the recipient) grafts undergo the same stages of the process [15].

4. 1. Peculiarities of the rejection response under allotransplantation. The allotransplantation response in populations of the REL type

This population system includes two parental species and the hybrid. The process of recognition of foreign antigens of the major histocompatibility complex of green frogs for all three genetic forms follows a common pattern: from engraftment to complete rejection. The differences relate to the rate of recognition of "selfbelonging - alien." For the hybrids the duration of the lag phase exceeds that of the marsh and edible frogs (Table 1). At the same time, the rate of the reaction as a whole, taking into account the graft survival time and data regression analysis, is higher in the hybrids.

Biochemical gene marking found that hybrids of this population system could be divided into allodiplod hybrids of $F_{1}$ structure and recombinant hybrids. The results showed that according to the allogenic variability of transplantation antigens different genetic forms of the hybrids are at a similar level. This is evidenced by the almost same duration of the latent phase and its coefficient of variation, but the allograft survival time and the reaction rate significantly differs between the two groups of hybrids (Table 2). 
Table 1

Results of the allotransplantation in green frog hybrid complex P. esculentus-ridibundus of the REL type of population

\begin{tabular}{|l|c|c|c|}
\hline \multicolumn{1}{|c|}{ Species/hybrid } & P. ridibundus & P. esculentus & $\begin{array}{c}\text { P. esculentus- } \\
\text { ridibundus }\end{array}$ \\
\hline Options for transplantation & $\mathrm{R}_{\mathrm{x}} \leftrightarrow \mathrm{R}_{\mathrm{y}}$ & $\mathrm{L}_{\mathrm{x}} \leftrightarrow \mathrm{L}_{\mathrm{y}}$ & 19 \\
\hline Number of allografts & 12 & $\mathrm{E}_{\mathrm{x}} \leftrightarrow \mathrm{E}_{\mathrm{y}}$ \\
\hline Mean duration of the lag phase, days & $17,583 \pm 0,981$ & $20,053 \pm 1,115$ & 14 \\
\hline min - max & $10-22$ & $11-29$ & $23,143 \pm 1,309^{*}$ \\
\hline CV & 19,320 & 24,231 & 21,160 \\
\hline Mean time of graft survival, days & $63,222 \pm 6,920$ & $62,632 \pm 5,641$ & $54,417 \pm 3,615$ \\
\hline min - max & $29-94$ & $34-97$ & $41-83$ \\
\hline CV & 32,835 & 39,258 & 22,989 \\
\hline Rejection rate, regression coefficient & $0,075 \pm 0,004$ & $0,068 \pm 0,006$ & $0,095 \pm 0,009^{*}$ \\
\hline
\end{tabular}

Note: * - differences are statistically significant.

Table 2

Results of allotransplantation in different genetic forms hybrids of the REL type of population

\begin{tabular}{|c|c|c|c|c|c|}
\hline Hybrids & $\mathrm{n}$ & $\begin{array}{c}\text { Mean duration of the } \\
\text { lag phase, days }\end{array}$ & $\mathrm{CV}$ & $\begin{array}{c}\text { Mean time of graft } \\
\text { survival, days }\end{array}$ & Reaction rate \\
\hline Allodiploids & 30 & $15,30 \pm 0,32$ & $28,24 \pm 1,98$ & $34,27 \pm 0,92^{*}$ & $0,163 \pm 0,014^{*}$ \\
\hline Recombinants & 12 & $16,08 \pm 0,57$ & $28,29 \pm 3,28$ & $40,17 \pm 1,31^{*}$ & $0,180 \pm 0,013^{*}$ \\
\hline
\end{tabular}

Note: $n$ - number of grafts; *-differences are statistically significant

Experiments involving allotransplantation in the green frog complex $P$. esculentus-ridibundus of the REL system type of population showed that the parental species $P$. ridibundus and $P$. esculentus are variable in terms of antigens of major histocompatibility complex. The interspecific hybrid differs considerably by a less amount of variability of the relevant antigens, which is characteristic for different genetic forms of hybrids of this type of population system.

The allotransplantation response in populations of the RE type.

This population system consists of the marsh frog and the hybrid. The investigated samples of the green frogs were taken in channels of the Danube Delta. The principal difference between this population and other populations of the RE type is the elimination of the chromosome set of the marsh frog during the formation of gametes [11]. Allotransplantation results showed that RE population system type is characterized by the same pattern as the REL populations of the Middle Dnipro: the allograft rejection in hybrids begins later than in marsh frogs (Table 3).

The conducted immunogenetic analysis of the hybrid complex $P$. esculentus-ridibundus of the RE type population system of the Danube Delta has revealed differences between the marsh frog and the hybrid in terms of heterogeneity of the histocompatibility antigens. The delay in the recognition of foreign antigens in hybrids, compared with the marsh frog, shows a decline in their genetic diversity.

Table 3

Results of allotransplantation in the green frog hybrid complex P. esculentus-ridibundus in the RE type of population

\begin{tabular}{|l|c|c|c|c|}
\hline \multicolumn{1}{|c|}{ Year } & \multicolumn{2}{c|}{2002} & \multicolumn{2}{c|}{2003} \\
\hline Species/hybrid & P. ridibundus & $\begin{array}{c}\text { P. esculentus- } \\
\text { ridibundus }\end{array}$ & P. ridibundus & $\begin{array}{c}\text { P. esculentus- } \\
\text { ridibundus }\end{array}$ \\
\hline Options for transplantation & $\mathrm{R}_{\mathrm{x}} \leftrightarrow \mathrm{R}_{\mathrm{y}}$ & $\mathrm{E}_{\mathrm{x}} \leftrightarrow \mathrm{E}_{\mathrm{y}}$ & $\mathrm{R}_{\mathrm{x}} \leftrightarrow \mathrm{R}_{\mathrm{y}}$ & $\mathrm{E}_{\mathrm{x}} \leftrightarrow \mathrm{E}_{\mathrm{y}}$ \\
\hline Number of allografts & 9 & 12 & 66 & 8 \\
\hline Mean duration of the lag phase, days & $13,40 \pm 0,65^{*}$ & $19,09 \pm 0,84^{*}$ & $17,11 \pm 0,43^{*}$ & $20,63 \pm 0,63^{*}$ \\
\hline min - max & $11-15$ & $15-25$ & $11-22$ & $20-25$ \\
\hline CV & $15,94 \pm 3,16$ & $15,45 \pm 3,15$ & $18,86 \pm 1,49$ & $8,58 \pm 5,16^{*}$ \\
\hline Mean time of graft survival, days & $25,11 \pm 2,50$ & $29,50 \pm 0,58$ & $36,97 \pm 0,71$ & $45,63 \pm 3,19$ \\
\hline min - max & $13-32$ & $27-32$ & $22-55$ & $34-55$ \\
\hline CV & $29,90 \pm 5,92 *$ & $6,86 \pm 6,02 *$ & $15,52 \pm 3,22$ & $14,65 \pm 11,4$ \\
\hline Rejection rate, regression coefficient & $0,16 \pm 0,02 *$ & $0,26 \pm 0,01 *$ & $0,12 \pm 0,01 *$ & $0,15 \pm 0,02 *$ \\
\hline
\end{tabular}

Note: *-differences are statistically significant.

The allotransplantation response in populations of the LE type

The population system consists of the edible frog and hybrid. The results of the transplantation tests show a difference between hybrids of the LE system type compared with hybrids of REL and RE types. The degree of their genetic diversity related to the genes of the major histocompatibility complex is higher than that of the parent edible frog species (Table 4). 
Three populations of the LE type have been studied. Of these two populations are typical (Baryshivka and Nizhyn). As for the frogs from Minay, they have been considered to be a unisexual hybrid popula- tion featured by a clonal type of reproduction. Our immunogenetic studies have refuted this assumption [17]. Later on it was found that this population also belongs to the LE type.

Table 4

Results of allotransplantation in the green frog hybrid complex P. esculentus-ridibundus of the LE type of population

\begin{tabular}{|c|c|c|c|c|c|c|c|}
\hline Locality & \multicolumn{3}{|c|}{ Baryshivka } & \multicolumn{3}{|c|}{ Nizgyn } & \multirow{3}{*}{$\begin{array}{c}\text { Minay } \\
2003 \\
\text { P. esc.-rid. }\end{array}$} \\
\hline Year & 2002 & & & 2002 & & & \\
\hline Species/hybrid & P. esc.-rid. & $\begin{array}{c}P . \\
\text { esculentus }\end{array}$ & P. esc.-rid. & $\begin{array}{l}\text { P. esc.-rid. } \\
\text { (rec) }\end{array}$ & P. esc.-rid. & $\begin{array}{c}\text { P. esc.-rid. } \\
\text { (rec) }\end{array}$ & \\
\hline $\begin{array}{l}\text { Options for } \\
\text { transplantation }\end{array}$ & $\mathrm{E}_{\mathrm{x}} \leftrightarrow \mathrm{E}_{\mathrm{y}}$ & $\mathrm{L}_{\mathrm{x}} \leftrightarrow \mathrm{L}_{\mathrm{y}}$ & $\mathrm{E}_{\mathrm{x}} \leftrightarrow \mathrm{E}_{\mathrm{y}}$ & $\mathrm{E}_{\mathrm{x}} \leftrightarrow \mathrm{E}_{\mathrm{y}}$ & $\mathrm{E}_{\mathrm{x}} \leftrightarrow \mathrm{E}_{\mathrm{y}}$ & $\mathrm{E}_{\mathrm{x}} \leftrightarrow \mathrm{E}_{\mathrm{y}}$ & $\mathrm{E}_{\mathrm{x}} \leftrightarrow \mathrm{E}_{\mathrm{y}}$ \\
\hline Number of grafts & 24 & 16 & 20 & 17 & 15 & 16 & 35 \\
\hline $\begin{array}{l}\text { Mean duration of } \\
\text { the lag phase, } \\
\text { days }\end{array}$ & $15,67 \pm 1,58$ & $21,56 \pm 0,57^{*}$ & $17,25 \pm 0,72 *$ & $15,12 \pm 0,74$ & $11,47 \pm 0,58$ & $11,88 \pm 0,66$ & $21,86 \pm 0,73$ \\
\hline $\min -\max$, days & $8-36$ & $15-24$ & $11-22$ & $10-22$ & $8-14$ & $8-16$ & $14-35$ \\
\hline $\mathrm{CV}$ & 49,27 & 10,58 & 18,61 & 20,11 & 19,44 & 22,14 & 19,76 \\
\hline
\end{tabular}

Note: ${ }^{*}$-differences are statistically significant between the species and hybrid from one population.

It was found that hybrids in populations from the Middle Dnipro of type LE (Baryshivka and Nizhyn) are more variable in terms of the histocompatibility antigens than the parent species - the edible frog. This makes them different from hybrids of REL and RE types of population systems. High variability is characteristic for allodiploid hybrids with the structure of $F_{1}$ and for recombinant hybrids. Hybrids from Minay were less variable. Their histocompatibility antigen variability does not differ from that of the edible frog, reflecting the heterogeneity of populations of hybrids, even within the same of population type.

In the LE type from the Middle Dnipro there is a hemiclonal transmission of the R-genome (genome of the marsh frog). The L-genome (genome of the edible frog) each time comes up in a renovated version. Therefore, it is logical to assume that the level of heterogeneity of hybrids in such populations should approach that of the edible frog. However, a feature of the hybridization process in the Middle Dnipro area is the introgression of genetic material of the edible frog into the genome of the marsh frog, which leads to an increase in its diversity [16]. The level of recombinant hybrids in populations of this type is very high (amongst 45 hybrids from Nizhyn 24 were recombinant, meaning $53 \%$ of the sample). This, in our opinion, can explain the increased heterogeneity of hybrids compared to the edible frog in this population system. The Transcarpathian population of hybrids from Minay, by contrast, tends to show a reaction of the graft rejection similar to that of hybrids from southern Poland [18].

\section{der xenotransplantation}

The aim of the study was to establish for allodiploid hybrids the character of domination of the major histocompatibility complex genes of the parental species. Hybrids on the premeiotic stage show the elimination of the genome of one of the parental species. Therefore, a question arises on the effects of different genomes at the tissue level within a hybrid organism. We can assume varying degrees of affinity between the hybrid and the two species of green frogs, the marsh and edible frogs, meaning that the rejection of xenografts may be differential.

The xenotransplantation response after transplantations from parental species to hybrids. It was found that the length of the lag phase of the recognition by the hybrid of tissue antigens of the parental species varies. In terms of histocompatibility antigens the hybrids exhibit a greater affinity with the edible frog. The pattern has been set for green frogs from different types of hybrid populations (REL, RE, LE). The results of the process of rejection of xenografts of the marsh and edible frogs by the hybrids in population systems of different types of are summarized in Table 5-7.

Table 5

The results of xenotransplantation in the green frog hybrid complex P. esculentus-ridibundus of a REL type of population (reaction of the hybrids)

\begin{tabular}{|c|c|c|c|c|c|c|}
\hline \multirow{2}{*}{ Recipient } & \multirow{2}{*}{ Donor } & \multirow{2}{*}{ Year } & \multicolumn{5}{|c|}{ Mean duration of the lag phase, days } \\
\cline { 3 - 7 } & & & $\mathrm{n}$ & Min - max, day. & $\mathrm{M} \pm \mathrm{m}$ & $\mathrm{CV}$ \\
\hline \multirow{2}{*}{ Hybrid } & \multirow{2}{*}{ Marsh } & 2003 & 10 & $12-26$ & $14,60 \pm 1,30^{*}$ & $28,22 \pm 6,31$ \\
\cline { 3 - 7 } & & 2004 & 19 & $12-26$ & $16,53 \pm 0,86^{*}$ & $22,57 \pm 3,66$ \\
\hline \multirow{2}{*}{ Hybrid } & \multirow{2}{*}{ Edible } & 2003 & 8 & $16-28$ & $24,63 \pm 1,78^{*}$ & $3,41 \pm 0,85$ \\
\cline { 3 - 7 } & & 2004 & 18 & $15-28$ & $21,17 \pm 1,13^{*}$ & $22,72 \pm 3,79$ \\
\hline Hybrid & Hybrid & 2003 & 18 & $16-27$ & $24,33 \pm 1,03$ & $18,00 \pm 3,00$ \\
\hline
\end{tabular}

Note: *-differences between various types of transplantations are significant within the frame of one year 
Table 6

The results of xenotransplantation in the green frog hybrid complex P. esculentus-ridibundus of a RE type of population (reaction of the hybrids)

\begin{tabular}{|c|c|c|c|c|c|}
\hline \multirow{2}{*}{ Recipient } & \multirow{2}{*}{ Donor } & \multicolumn{4}{c|}{ Mean duration of the lag phase, days } \\
\cline { 3 - 6 } & \multicolumn{2}{|c|}{ Sample of RE population from Vylkove, 2004} & $\mathrm{M} \pm \mathrm{m}$ & CV \\
\hline Hybrid & Marsh & 15 & $13-17$ & $14,47 \pm 0,41^{*}$ & $11,06 \pm 2,02$ \\
\hline Hybrid & Edible & 15 & $15-20$ & $17,13 \pm 0,52^{*}$ & $11,68 \pm 2,13$ \\
\hline Hybrid & Hybrid & 12 & $15-25$ & $18,75 \pm 0,84$ & $15,45 \pm 3,15$ \\
\hline \multicolumn{7}{|c|}{ Sample of RE population from Tsehlivka, 2004 } \\
\hline Hybrid & Marsh & 8 & $9-14$ & $11,50 \pm 0,60^{*}$ & $14,70 \pm 3,68$ \\
\hline Hybrid & Edible & 8 & $16-23$ & $19,88 \pm 0,83^{*}$ & $11,87 \pm 2,97$ \\
\hline \multicolumn{7}{|c|}{ Sample of RE population from Haydary, 2005 } \\
\hline Hybrid & Marsh & 26 & $11-18$ & $13,96 \pm 0,41^{*}$ & $14,97 \pm 2,08$ \\
\hline Hybrid & Edible & 26 & $13-22$ & $16,88 \pm 0,44^{*}$ & $13,21 \pm 1,83$ \\
\hline
\end{tabular}

Note: *-differences between various types of transplantations are significant within the timeframe of one year

Table 7

The results of xenotransplantation in the green frog hybrid complex $P$. esculentus-ridibundus of a LE type of population (reaction of the hybrids)

\begin{tabular}{|c|c|c|c|c|c|}
\hline \multirow{2}{*}{ Recipient } & \multirow{2}{*}{ Donor } & \multicolumn{4}{|c|}{ Mean duration of the lag phase, days } \\
\hline & & $\mathrm{n}$ & Min - max, day & $\mathrm{M} \pm \mathrm{m}$ & $\mathrm{CV}$ \\
\hline \multicolumn{6}{|c|}{ Sample of LE population from Baryshivka, 2004} \\
\hline Hybrid & Marsh & 19 & $8-22$ & $15,37 \pm 0,91$ & $25,67 \pm 4,16$ \\
\hline Hybrid & Edible & 20 & $13-20$ & $17,15 \pm 0,45$ & $11,72 \pm 1,85$ \\
\hline Hybrid & Hybrid & 20 & $11-24$ & $17,25 \pm 0,72$ & $18,61 \pm 2,94$ \\
\hline \multicolumn{6}{|c|}{ Sample of LE population from Nizhyn, 2005} \\
\hline Hybrid & Marsh & 9 & $6-16$ & $11,72 \pm 1,02 *$ & $26,06 \pm 6,14$ \\
\hline Hybrid & Edible & 9 & $12-18$ & $15,44 \pm 0,87 *$ & $16,84 \pm 3,97$ \\
\hline Hybrid & Hybrid & 15 & $8-14$ & $11,47 \pm 0,58$ & $20,23 \pm 3,69$ \\
\hline
\end{tabular}

Note: *-differences are statistically significant within each sample

The xenotransplantion response following transplantations of grafts from the hybrids to the parental species. Differences have also been found between the species in terms of the rate of the rejection of transplanted from the hybrids grafts (Table 8-10). The marsh frog perceives hybrid tissue as closely related. For the edible frog tissue antigens of the hybrid are alien to the same extent as antigens of the marsh frog. The results of the exchange of xenografts between the edible and marsh frogs indicate a different degree of their immunogenicity and, as far as in terms of species-specific antigens they are equally alien to each other, the edible frog rejects the tissue of the marsh frog significantly earlier. The described trend, as well as the hybrid reaction towards antigens of the parental species, is valid for all types of studied populations, regardless of their geographical location and species composition of the hybrid complex.

Table 8

The results of xenotransplantation in the green frog hybrid complex P. esculentus-ridibundus of a REL type of population (reaction of the parental species)

\begin{tabular}{|c|c|c|c|c|c|c|}
\hline \multirow{2}{*}{ Recipient } & \multirow{2}{*}{ Donor } & \multirow{2}{*}{ Year } & \multicolumn{4}{|c|}{ Mean duration of the lag phase, days } \\
\hline & & & $\mathrm{n}$ & Min - max, day. & $\mathrm{M} \pm \mathrm{m}$ & $\mathrm{CV}$ \\
\hline \multirow{2}{*}{ Marsh } & \multirow{2}{*}{ Hybrid } & 2003 & 12 & $9-33$ & $23,33 \pm 1,78^{*}$ & $26,19 \pm 5,35$ \\
\hline & & 2004 & 18 & $9-33$ & $22,56 \pm 1,21 *$ & $22,70 \pm 3,78$ \\
\hline \multirow{2}{*}{ Edible } & \multirow{2}{*}{ Hybrid } & 2003 & 9 & $12-17$ & $14,33 \pm 0,60 *$ & $12,56 \pm 2,96$ \\
\hline & & 2004 & 15 & $12-22$ & $15,93 \pm 0,83^{*}$ & $20,21 \pm 3,69$ \\
\hline Marsh & Edible & 2004 & 6 & $20-22$ & $21,33 \pm 0,42$ & $4,83 \pm 1,39$ \\
\hline Edible & Marsh & 2004 & 5 & $14-22$ & $18,40 \pm 1,57$ & $19,08 \pm 6,03$ \\
\hline Marsh & Marsh & 2003 & 12 & $10-22$ & $17,58 \pm 0,98 *$ & $19,34 \pm 3,95$ \\
\hline Edible & Edible & 2003 & 17 & $16-29$ & $21,12 \pm 0,94 *$ & $18,42 \pm 3,16$ \\
\hline
\end{tabular}


Table 9

The results of xenotransplantation in the green frog hybrid complex $P$. esculentus-ridibundus of a RE type of population (reaction of the parental species)

\begin{tabular}{|c|c|c|c|c|c|}
\hline \multirow[b]{2}{*}{ Recipient } & \multirow[b]{2}{*}{ Donor } & \multicolumn{4}{|c|}{ Mean duration of the lag phase, days } \\
\hline & & $\mathrm{n}$ & Min - max, day. & $M \pm m$ & $\mathrm{CV}$ \\
\hline \multicolumn{6}{|c|}{ Sample of RE population from Vylkove, 2004} \\
\hline Marsh & Hybrid & 19 & $15-27$ & $18,32 \pm 0,68 *$ & $16,27 \pm 2,64$ \\
\hline Edible & Hybrid & 18 & $13-20$ & $16,06 \pm 0,60 *$ & $15,88 \pm 2,65$ \\
\hline Marsh & Edible & 19 & $13-27$ & $16,95 \pm 0,98 *$ & $25,13 \pm 4,08$ \\
\hline Edible & Marsh & 19 & $10-17$ & $14,42 \pm 0,48 *$ & $14,49 \pm 2,35$ \\
\hline Marsh & Marsh & 9 & $11-15$ & $13,22 \pm 0,70$ & $15,94 \pm 3,76$ \\
\hline \multicolumn{6}{|c|}{ Sample of RE population from Tsehlivka, 2004} \\
\hline Marsh & Hybrid & 4 & $16-19$ & $16,75 \pm 0,75^{*}$ & $8,96 \pm 3,17$ \\
\hline Edible & Hybrid & 7 & $7-12$ & $10,43 \pm 0,78^{*}$ & $19,85 \pm 5,31$ \\
\hline Marsh & Edible & 4 & $21-26$ & $22,75 \pm 1,18^{*}$ & $10,37 \pm 3,67$ \\
\hline Edible & Marsh & 8 & $7-14$ & $10,00 \pm 1,00 *$ & $28,30 \pm 2,59$ \\
\hline \multicolumn{6}{|c|}{ Sample of RE population from Haydary, 2005} \\
\hline Marsh & Hybrid & 27 & $13-27$ & $18,19 \pm 0,87^{*}$ & $24,90 \pm 3,39$ \\
\hline Edible & Hybrid & 27 & $11-19$ & $12,52 \pm 0,37 *$ & $15,26 \pm 2,08$ \\
\hline Marsh & Edible & 27 & $13-27$ & $20,30 \pm 0,74 *$ & $18,97 \pm 2,58$ \\
\hline Edible & Marsh & 25 & $11-15$ & $11,84 \pm 0,23 *$ & $9,63 \pm 1,36$ \\
\hline
\end{tabular}

Note: *-differences between various types of transplantations of grafts from hybrids to parental species and within the control group are significant within the frame of one year

Table 10

The results of xenotransplantation in the green frog hybrid complex $P$. esculentus-ridibundus of a LE type of population (reaction of the parental species)

\begin{tabular}{|c|c|c|c|c|c|}
\hline \multirow{2}{*}{ Recipient } & \multirow{2}{*}{ Donor } & \multicolumn{5}{c|}{ Mean duration of the lag phase, days } \\
\cline { 3 - 6 } & \multicolumn{7}{|c|}{ Sample of LE population from Baryshivka, 2004 } & M m & CV \\
\hline Marsh & Hybrid & 18 & $8-20$ & $16,67 \pm 0,94^{*}$ & $23,82 \pm 3,97$ \\
\hline Edible & Hybrid & 20 & $8-15$ & $11,65 \pm 0,61^{*}$ & $23,35 \pm 3,69$ \\
\hline Marsh & Edible & 19 & $11-22$ & $15,90 \pm 0,67^{*}$ & $18,24 \pm 2,96$ \\
\hline Edible & Marsh & 18 & $11-15$ & $12,56 \pm 0,41^{*}$ & $14,01 \pm 2,34$ \\
\hline Edible & Edible & 16 & $15-24$ & $21,56 \pm 0,57$ & $10,60 \pm 1,87$ \\
\hline \multicolumn{7}{|c|}{ Sample of LE population from Nizhyn, 2005 } \\
\hline Marsh & Hybrid & 9 & $11-17$ & $12,56 \pm 0,63$ & $14,97 \pm 3,53$ \\
\hline Edible & Hybrid & 9 & $6-16$ & $11,11 \pm 1,11$ & $29,97 \pm 7,06$ \\
\hline Marsh & Edible & 9 & $12-16$ & $13,78 \pm 0,49$ & $10,74 \pm 2,53$ \\
\hline Edible & Marsh & 9 & $6-14$ & $10,56 \pm 0,82$ & $23,30 \pm 5,49$ \\
\hline Edible & Edible & 13 & $8-16$ & $11,39 \pm 0,76$ & $23,88 \pm 4,68$ \\
\hline
\end{tabular}

Note: *-differences between various types of transplantations of grafts from hybrids to parental species and within the control group are significant within the frame of one year

\section{Discussion of the results}

The results of the allotransplantations regarding the parental species can be considered predictable and they agree well with those obtained by using other methods, including morphological analysis and biochemical gene marking. The marsh frog is an evolutionarily novel, ecologically plastic species that is featured by a high degree of polymorphism [19]. This is manifested as well at the tissue level. The short duration of the latent phase during intraspecific transplantations amongst marsh frogs shows a high heterogeneity for this species in terms of transplantation antigens.

The edible frog exhibits reduced, compared to the marsh frog, allogeneic heterogeneity of antigens of the major histocompatibility complex; this also is consistent with conclusions reached by other approaches.
In hybrids heterogeneity of the histocompatibility locus in general is decreased, as compared to the parental species. But we must distinguish between diversity within each individual population (where it can actually be reduced) and the diversity of hybrids exemplified by the origin from different types of populations and habitats. The source of hybrids clearly divided into two groups: hybrids that have arisen de novo as a result of cross breeding of parental species and hybrids resulting from back crosses. The latter group is heterogeneous, its composition is determined by which genome is eliminated during gametogenesis. If this is the genome of the edible frog, the hybrids are produced by the cross breeding of hybrids - edible frog, if this is the genome of the marsh frog then hybrids are produced by cross breeding with other marsh 
frogs, if no elimination takes place then triploids are formed. Theoretically hybrid origin should not affect their biological characteristics, because the elimination takes place at premeiotic stages and the off-spring should obtain a "clean" genome. However, this is not the case because the cross breeding of hybrids does not produce viable offspring [20], indicating hybrid dysgenesis and therefore the genetic structure of first generation of hybrids and hybrids produced by back-crossing should be different. And this indeed is manifested, first and for all, in the different sexual structure of hybrids from different geographic locations and types of population, even within Ukraine [6,11].

The conducted analysis of the variability of antigens of the major histocompatibility complex also confirms the genetic heterogeneity of hybrids from different types of populations. In a population of the REL type from the Middle Dnipro the immune response of hybrids is apparently delayed compared to the parental species. This may indicate that the level of polymorphism of the major histocompatibility complex antigens in hybrids is lower. This can be explained by the fact that hybrids in this population are formed as a result of sporadic crosses between either parental species or either hybrids and the edible frog. Although it is possible that the characteristics of the immune response by the hybrids is a consequence of dysgenesis that is revealed, for instance, in the deformed sexual structure of the hybrids.

Hybrids from populations of the LE type, in contrast to hybrids of the REL type, have a shorter latent phase compared to the parental species. This indicates a possible higher intra-population heterogeneity of hybrid populations of this type in terms of transplantation antigens, which can be explained firstly by the fact that hybrids produced by back-crossing, can appear many times, and mating between males of edible frogs and hybrid females (due to their ecological and biological proximity) can occur much more easily than between the parental species. Secondly, the introgressive nature of hybridization, especially characteristic for the Dnipro Basin [16], leads to the fact that all back-cross hybrids of each consecutive generation are gaining a larger share of genes from the marsh frog, tissues of which (as shown by the xenotransplantation experiments) have a higher immunogenicity.

This difference in the degree introgression can do much to explain the particular nature of the transplant response of hybrids from different parts of their home range. This applies in particular populations of the RE type from Vylkove. At the first glance, a sharp and significant delayed transplantation response in hybrids compared to mash frogs is quite predictable and confirms the results from samples obtained in the Dnipro Basin. But hybrids of the Danube Delta and the Middle Dnipro are significantly different considering a number of features. Firstly, hybrids from Vylkove have an equal sex ratio, and secondly, they eliminated the genome of the marsh frog, not the edible frog, and, thirdly, here are no records of the introgression of nuclear genes [16].

However, the most likely explanation for the delay of the immune response by the Danube hybrids, like those from the Middle Dnipro maybe their genetic relationship. In the wetlands of the Danube the hybrids are few in numbers and highly concentrated in channels, from which they were taken for the study, so the "founder effect" may be true for them.

Given the allogeneic variability of the hybrids, which depends on the type of cross breeding and on the characteristics inherent in different hybrid zones, a question arises upon the relationship of hybrids to one or the other parent species at the tissue level, and what this relationship depends on.

In hybrids from all geographical regions (Danube wetlands, Transcarpathia, Middle Dnipro, Siversky Donets basins) there is a clearly faster rejection of grafts of the marsh frog compared to transplants involving the edible frog. This does not matter whether the donor species was taken from one area with the hybrids or species that was absent in the studied type of population was taken from another area.

The geographical location of the population, which determines the nature of inheritance of the parental genomes, did not affect the rate of recognition by the immune system the grafts of the parental species.

It follows that for the hybrids of green frogs the inheritance of the major histocompatibility complex genes involves the dominance of the edible frog over the marsh frog, so at the tissue level hybrids perceive somatic tissues of edible frogs as related, whereas those of the marsh frog as alien.

At the same time, based on xenotransplantation responses of the parental species towards hybrid grafts, we can conclude that transplantation antigens of the edible frog have a lower immunogenicity and marsh a higher one. This is why hybrid grafts were perceived by the edible frogs as "marsh" and caused a rapid rejection response, but for the marsh frogs the hybrid grafts appeared as "edible" immunogentic antigens of weak power.

In this case, the higher affinity of hybrid forms with the edible frog does not correlate with the trend towards the elimination of parental genomes in hybrids, but is consistent with the dominance of morphological and ecological traits of the edible frog over those the marsh frog. Thus, not only at the cellular and whole organism level, but also at the tissue level within the complex of green frogs a genetic asymmetry of the hybrids is observed.

\section{Conclusions}

1. The green frog hybrid complex Pelophylax esculentus-ridibundus, namely the marsh $P$. ridibundus, edible $P$. esculentus, as well as allodiploid hybrids P. esculentus-ridibundus are characterized by the polymorphism of the major histocompatibility complex. The most variable are species. Hybrids are less variable in terms of antigens of histocompatibility.

2 . The analysis of the variability of major histocompatibility complex antigens also confirms the genetic heterogeneity of hybrids from different types of populations.

3. The inheritance of the major histocompatibility complex genes by the hybrids of green frogs involves the dominance of the edible frog over the marsh frog, so at the tissue level hybrids perceive so- 
matic tissues of edible frogs as related, whereas those of the marsh frog as alien.

4. The greater affinity of hybrid forms with the edible frog does not correlate in any way with the trend of elimination of parental genomes in the hybrids, but coincides with the dominance of morphological and ecological traits of the edible frog over the marsh frog.

\section{References}

1. Berger, L. Western Palearctic water frogs (Amphibia, Ranidae): systematics, genetics and population compositions [Text] / L. Berger // Experientia. - 1983. - Vol. 39, Issue 2. - P. 127-130. doi: 10.1007/bf01958859

2. Tunner, H. G. Die klonale Struktur einer Wasserfrosch population [Text] / H. G. Tunner // Journal of Zoological Systematics and Evolutionary Research. - 1974. - Vol. 12, Issue 4. - P. 309-314. doi: 10.1111/j.1439-0469.1974.tb00173.x

3. Günther, R. Der Karyotyp von Rana ridibunda Pall. und das Vorkommen von Triploidie bei Rana esculenta L. (Anura, Amphibia) [Text] / R. Günther // Biologisches Zentralblatt. - 1970. - Vol. 89, Issue 3. - P. 327-342.

4. Tunner, H. G. Die klonale Struktur einer Wasserfrosch population [Text] / H. G. Tunner // Journal of Zoological Systematics and Evolutionary Research. - 1974. - Vol. 12, Issue 1. - P. 309-314. doi: 10.1111/j.1439-0469.1974.tb00173.x

5. Graf, J.-D. Cytogenetic analysis of spermatogenesis in unisexual allotriploid males from a Rana lessonae Rana kl. esculenta mixed population [Text] / J.-D. Graf, M. P. Polls-Pelaz. - First World Congress of Herpetology. University of Kent Canterbury, 1989. - P. 124-136.

6. Nekrasova, O. D. Struktura populyatsiy i gibridizatsiya zelenyih lyagushek (Rana esculenta complex) urbanizirovannyih territoriy Srednego Pridneprovya: [Population structure and hybridization green frogs (Rana esculenta complex) urbanized areas of the Middle Dnieper] [Text] / O. D. Nekrasova. - Institute of zoology, Ukrainian Academy of Sciences. Kiev, 2002. -19 p.

7. Berger, L. Sex determination and sex ratios in western Palearctic water frogs: $\mathrm{XX}$ and $\mathrm{XY}$ female hybrids in the Pannonian Basin? [Text] / L. Berger, T. Uzzell, H. Hotz // Proceedings of the Academy of Natural Sciences of Philadelphia - 1988. - Vol. 140, Issue 1. - P. 220-239.

8. Berger, L. On the origin of genetic systems in European water frog hybrids [Text] / L. Berger // Zoologica Poloniae. - 1990. - Vol. 35, Issue 1-4. - P. 5-32.

9. Vinogradov, A. E. Two germ cell lineages with genomes of different species in one and the same animal [Text] / A. E. Vinogradov, L. J. Borkin, R. Günther, J. M Rosanov // Hereditas. - 1991. - Vol. 114, Issue 3. - P. 245-251. doi: 10.1111/j.1601-5223.1991.tb00331.x

10. Mezhzherin, S. V. Populyatsionno-geneticheskiy analiz strukturyi gibridnyih populyatsiy Rana esculenta complex [Population genetic analysis of the structure of hybrid populations of Rana esculenta complex] [Text] / S. V. Mezhzherin, S. Yu. Morozov-Leonov // Tsitologiya i genetika. 1993. - Vol. 27, Issue 2. - P. 63-68.

11. Morozov-Leonov, S. Yu. (). Gibridizatsiya amfibiy: struktura populyatsiy, evolyutsiyni naslidki, status gibridnih biotipiv. [Hybridization of amphibians: the structure of populations, evolutionary consequences, the status of hybrid biotypes] [Text] / S. Yu. Morozov-Leonov. - Institute of zoology, Ukrainian Academy of Sciences. Kiev, 2014. - 36 p.

12. Cohen, N. Amphibian Transplantation Reactions: A Review [Text] / N. Cohen // Integrative and Comparative Biology. - 1971. - Vol. 11, Issue 2. - P. 193-205. doi: 10.1093/ $\mathrm{icb} / 11.2 .193$
13. Płytycz, B. Differential polymorphism of the amphibian MHC [Text] / B. Płytycz // Developmental \& Comparative Immunology. - 1984. - Vol. 8, Issue 3. - P. 727-732. doi: $10.1016 / 0145-305 \times(84) 90104-6$

14. Płytycz, B. Rejection of skin allo- and xenografts in the grass frog, Rana temporaria and the edible frog, Rana esculenta [Text] / B. Płytycz, D. Semik // Archivum immunologiae et therapiae experimentalis. - 1980. Vol. 28. - P. 625-634.

15. Kozinenko, I. I. Osobennosti allotransplantatsii v gibridnom komplekse zelenyih lyagushek Rana esculenta. [Features allotransplantation in the hybrid complex of green frog Rana esculenta] [Text] / I. I. Kozinenko, E. I. Zhalay, N. S. Zavodnikova // Vestnik zoologii. - 2006. - Vol. 40, Issue 1. - P. 49-53.

16. Mezhzherin S. V. Diffuzii genov v gibridnyih populyatsiyah zelenyih lyagushek Rana esculenta L., 1758 complex (Amphibia, Ranidae) Pridneprovya [Diffusion of genes in hybrid populations of green frogs Rana esculenta L., 1758 complex (Amphibia, Ranidae) Pridneprovya] [Text] / S. V. Mezhzherin, S. Yu. Morozov-Leonov // Genetika. 1997. - Vol. 33, Issue 3. - P. 358-364.

17. Zhalay O. I. Analiz odnostatevoyi gibridnoyi populyatsiyi zhab Rana esculenta complex Zakarpattya metodom transplantatsiyi shkiri [Analysis of unisexual hybrid populations frog Rana esculenta complex Transcarpathia by transplantation of skin] [Text] / O. I. Zhalay, I. I. Kozinenko // Nauk. visnik Uzhgorodskogo universitetu. Seriya Biologiya. 2005. - Vol. 16. - P. 176-179.

18. Semik, D. Comparison of reactions to skin grafts in green frogs: Rana lessonae Cam., $R$. esculenta L. and $R$. ridibunda Pall [Text] / D. Semik // Archivum immunologiae et therapiae experimentalis. - 1983. - Vol. 31. - P. 429-436.

19. Terentev P. V. Korrelyatsii indeksov ozernoy lyagushki Rana ridibunda Pall [Correlation indices lake frog Rana ridibunda Pall] [Text] / P. V. Terentev // Zool. zhurnal. 1943. - Vol. 43, Issue 3. - P. 175-181.

20. Berger, L. Yavlyaetsya li prudovaya lyagushka Rana esculenta complex obyiknovennyim gibridom? [Is the pond frog Rana esculenta complex ordinary hybrid?] [Text] / L. Berger // Ekologiya. - 1976. - Vol. 2. - P. 37-43.

\section{References}

1. Berger, L. (1983). Western Palearctic water frogs (Amphibia, Ranidae): systematics, genetics and population compositions. Experientia, 39 (2), 127-130. doi: 10.1007/ bf01958859

2. Tunner, H. G. (1974). Die klonale Struktur einer Wasserfrosch population. Journal of Zoological Systematics and Evolutionary Research, 12 (4), 309-314.

doi: 10.1111/j.1439-0469.1974.tb00173.x

3. Günther, R. (1970). Der Karyotyp von Rana ridibunda Pall. und das Vorkommen von Triploidie bei Rana esculenta L. (Anura, Amphibia). Biologisches Zentralblatt. 89 (3), 327- 342 .

4. Tunner, H. G. (1974). Die klonale Struktur einer Wasserfrosch population. Zeitschrift für zoologische Systematik und Evolutionsforschung, 12 (4), 309-314. doi: 10.1111/ j.1439-0469.1974.tb00173.x

5. Graf, J.-D., Polls-Pelaz, M. P. (1989). Cytogenetic analysis of spermatogenesis in unisexual allotriploid males from a Rana lessonae - Rana kl. esculenta mixed population. First World Congress of Herpetology. University of Kent Canterbury, 124-136.

6. Nekrasova, O. D. (2002). Struktura populyatsiy i gibridizatsiya zelenyih lyagushek (Rana esculenta complex) urbanizirovannyih territoriy Srednego Pridneprovya:[ Population structure and hybridization green frogs (Rana esculenta complex) urbanized areas of the Middle Dnie- 
per]. Institute of zoology, Ukrainian Academy of Sciences. Kiev, 19.

7. Berger, L., Uzzell, T., Hotz, H. (1988). Sex determination and sex ratios in western Palearctic water frogs: $\mathrm{XX}$ and $\mathrm{XY}$ female hybrids in the Pannonian Basin? Proceedings of the Academy of Natural Sciences of Philadelphia, 140 (1), 220-239.

8. Berger, L. (1990). On the origin of genetic systems in European water frog hybrids. Zoologica Poloniae, 35 (1-4), 5-32.

9. Vinogradov, A. E., Borkin, L. J., Günther, R., Rosanov, J. M. (1991). Two germ cell lineages with genomes of different species in one and the same animal. Hereditas, 114, 245-251. doi: 10.1111/j.1601-5223.1991. tb00331.x

10. Mezhzherin, S. V., Morozov-Leonov, S. Yu. (1993). Populyatsionno-geneticheskiy analiz strukturyi gibridnyih populyatsiy Rana esculenta complex [Population genetic analysis of the structure of hybrid populations of Rana esculenta complex]. Tsitologiya i genetika, 27 (2), 63-68.

11. Morozov-Leonov, S. Yu. (2014). Gibridizatsiya amfibiy: struktura populyatsiy, evolyutsiyni naslidki, status gibridnih biotipiv. [Hybridization of amphibians: the structure of populations, evolutionary consequences, the status of hybrid biotypes]. Institute of zoology, Ukrainian Academy of Sciences. Kiev, 36.

12. Cohen, N. (1971). Amphibian Transplantation Reactions: A Review. Integrative and Comparative Biology, 11 (2), 193-205. doi: 10.1093/icb/11.2.193

13. Płytycz, B. (1984). Differential polymorphism of the amphibian MHC. Developmental \& Comparative Immunology, 8 (3), 727-732. doi: 10.1016/0145-305x(84) 90104-6
14. Płytycz, B., Semik, D. (1980). Rejection of skin allo- and xenografts in the grass frog, Rana temporaria and the edible frog, Rana esculenta. Archivum immunologiae et therapiae experimentalis, 28, 625-634.

15. Kozinenko, I. I., Zhalay, E. I., Zavodnikova, N. S. (2006). Osobennosti allotransplantatsii v gibridnom komplekse zelenyih lyagushek Rana esculenta. [Features allotransplantation in the hybrid complex of green frog Rana esculenta]. Vestnik zoologii, 40 (1), 49-53.

16. Mezhzherin, S. V., Morozov-Leonov, S. Yu. (1997). Diffuzii genov v gibridnyih populyatsiyah zelenyih lyagushek Rana esculenta L., 1758 complex (Amphibia, Ranidae) Pridneprovya [Diffusion of genes in hybrid populations of green frogs Rana esculenta L., 1758 complex (Amphibia, Ranidae) Pridneprovya]. Genetika, 33 (3), 358-364.

17. Zhalay, O. I., Kozinenko, I. I. (2005). Analiz odnostatevoyi gibridnoyi populyatsiyi zhab Rana esculenta complex Zakarpattya metodom transplantatsiyi shkiri [Analysis of unisexual hybrid populations frog Rana esculenta complex Transcarpathia by transplantation of skin]. Nauk. visnik Uzhgorodskogo universitetu. Seriya Biologiya, $16,176-179$.

18. Semik, D. (1983). Comparison of reactions to skin grafts in green frogs: Rana lessonae Cam., $R$. esculenta L. and $R$. ridibunda Pall. Archivum immunologiae et therapiae experimentalis, 31, 429-436.

19. Terentev, P. V. (1943) Korrelyatsii indeksov ozernoy lyagushki Rana ridibunda Pall. [Correlation indices lake frog Rana ridibunda Pall]. Zool. zhurnal, 43 (3), 175-181.

20. Berger, L. (1976). Yavlyaetsya li prudovaya lyagushka Rana esculenta complex obyiknovennyim gibridom? [Is the pond frog Rana esculenta complex ordinary hybrid?]. Ekologiya, 2, 37-43.

Рекомендовано до публікації д-р біол. наук, професор Межжерін С. В. Дата надходження рукопису 24.02.2015

Iryna Kozynenko, Researcher, PhD, Schmalhausen Institute of Zoology NAS of Ukraine, Bohdan Khmelnytskyst, 15, Kiev, Ukraine, 01601 E-mail: kozinenko@gmail.com

Elena Zhalai, Researcher, PhD, Schmalhausen Institute of Zoology NAS of Ukraine, Bohdan Khmelnytskyst, 15, Kiev, Ukraine, 01601

E-mail:zhalai@ukr.net 